\title{
A close relationship between algicidal bacteria and termination of Heterosigma akashiwo (Raphidophyceae) blooms in Hiroshima Bay, Japan
}

\author{
Mu-Chan Kim ${ }^{1}$, Ikuo Yoshinaga ${ }^{1, *}$, Ichiro Imai $^{1}$, Keizo Nagasaki $^{2}$, Shigeru Itakura ${ }^{2}$, \\ Yuzaburo Ishida ${ }^{3}$
}

${ }^{1}$ Laboratory of Marine Microbiology, Division of Applied Biosciences, Graduate School of Agriculture, Kyoto University, Kyoto 6068502, Japan

${ }^{2}$ Red Tide Research Division, Nansei National Fisheries Research Institute, Ohno, Saeki, Hiroshima 7390452, Japan

${ }^{3}$ Faculty of Engineering, Fukuyama University, Fukuyama, Hiroshima 7290292, Japan

\begin{abstract}
Blooms of the noxious red tide phytoplankton Heterosigma akashiwo (Raphidophyceae) occurred in Hiroshima Bay, Japan, in 1994 and 1995. During these blooms we monitored microorganisms which killed $H$. akashiwo by use of the microplate MPN (most probable number) method using an axenic culture of $H$. akashiwo as a susceptible host organism. At every sampling site abundance of algicidal microorganisms in seawater samples filtered through $0.8 \mu \mathrm{m}$ nuclepore filters increased rapidly during the termination period of each bloom. However, the number of algicidal microorganisms in seawater samples filtered through $0.2 \mu \mathrm{m}$ nuclepore filters was less abundant and correlated poorly with the extinction of $H$. akashiwo blooms. The latter samples were assumed to indicate viral activity. Thus, it is possible that $H$. akashiwo-killing bacteria (HAKB) played a more dominant role in the termination of the blooms in 1994 and 1995 in Hiroshima Bay than viruses. The number of algicidal bacteria targeting Chattonella antiqua (Raphidophyceae), which was not detected during the investigation period, was 1 or 2 orders of magnitude lower than that of HAKB. We isolated some HAKB strains capable of causing mortality in $H$. akashiwo. These results suggest that the population dynamics of algicidal bacteria has a close relationship to the blooms of the phytoplankton, and that, in marine ecosystems, algicidal bacteria targeting specific phytoplankton may be one of the agents which regulate the change of species structure of phytoplankton communities.
\end{abstract}

KEY WORDS: Algicidal bacteria - Marine bacteria - Marine phytoplankton - Red tide $\cdot$ Bloom - Raphidophyceae - Heterosigma akashiwo

\section{INTRODUCTION}

Many physical and chemical environmental factors, such as light, temperature, organic and inorganic substances, etc., regulate the change of species composition in phytoplankton populations. Zooplankton, bacteria and viruses living with phytoplankton also influence the dynamics of phytoplankton populations by means of predation, competition, and production of stimulatory or inhibitory substances for plankton growth (Cole 1982, Jones 1982, Anderson et al. 1983, Riquelme \& Ishida 1989, Nakamura et al, 1992, 1995, Jeong \& Latz

\footnotetext{
- Addressee for correspondence.

E-mail: iyoshina@kais.kyota-u.ac.jp
}

1994, Kamiyama 1994, 1995). Currently, algicidal bacteria and viruses are considered to be significant agents in the dramatic termination of microalgal blooms frequently observed in coastal seawaters (Honjo 1992, Sutthe 1994, Bratbak et al. 1995, Yoshinaga et al. 1995b).

Suttle \& Chan (1995) isolated infectious viruses specific for the marine haptophytes Chrysochromulina brevifilum and $C$. strobilus from coastal seawater and discussed the significance of viral activity on plankton populations. Bratbak et al. $(1993,1995)$ suggested, based on the results of a mesocosm study, that viral activity may prevent or terminate the development of Emiliania huxleyi blooms. Nagasaki et al. $(1993,1994)$ observed the increase of virus-like particles (VLPs) in Heterosigma akashiwo cells at the final stage of a red 
tide caused by this alga. These results supported the significance of viral impacts on the rapid termination of phytoplankton blooms.

In addition, many bacteria which kill and/or lyse microalgal cells have been isolated from various coastal seawaters (Baker \& Herson 1978, Ishio et al. 1989, Sakata 1990, Imai et al. 1991, 1993a, 1995, Fukami et al. 1992, Mitsutani et al. 1992, Yoshinaga et al. 1995a, 1997). Although some gliding bacteria lysed a wide variety of marine phytoplankton, including diatoms, dinoflagellates and raphidophycean flagellates, some Vibrio, Acinetobacter and Flavobacterium had killing activities with high host specificity (Fukami et al. 1992, Yoshinaga et al. 1997). Though these algicidal bacteria may also influence phytoplankton communities, there are few ecological studies on the dynamics of microorganisms (especially bacteria and viruses) algicidal to certain phytoplankton in relation to the development and decay process of the phytoplankton bloom. Fukami et al. (1991) demonstrated, using a modified AGP (algal growth potential) method, that the bacterial assemblage which specifically inhibited the growth of Gymnodinium mikimotoi (Dynophyceae) influenced the succession from a $G$. mikimotoi bloom to a Skeletonema costatum (Bacillariophyceae) bloom in the Uranouchi Inlet, Kochi, Japan. Yoshinaga et al. (1995b) also enumerated the bacteria which inhibited the growth of G. mikimotoi ( $G$. mikimotoi growth inhibiting bacteria, Gm-GIB) with the newly developed most probable number (MPN) method, and found a negative correlation between the abundance of $G$. mikimotoi and that of Gm-GIB during the development and decay process of huge red tides of G. mikimotoi in Tanabe Bay, Wakayama, Japan.

The final goal of our research program is to elucidate the role of microbial impact, especially bacterial and viral activities, on marine microalgal bloom dynamics and to be able to apply microorganisms to prevent and terminate the harmful blooms. In this study, we investigated the changing abundance of the algicidal microorganisms in the $<0.8 \mu \mathrm{m}$ (including mainly bacteria and viruses) and $<0.2 \mu \mathrm{m}$ (including mainly viruses) size fractions which killed Heterosigma akashiwo during the bloom of $H$. akashiwo by the MPN method using an axenic culture of $H$. akashiwo as a host organism.

\section{MATERIALS AND METHODS}

Microalgae. An axenic culture of Heterosigma akashiwo (893) was isolated from Hiroshima Bay, Seto Inland Sea, Japan (Imai et al. 1993b), and an axenic culture of Chattonella antiqua (NIES-1, Raphidophyceae) was provided by the National Institute for Environmental Study, the Environment Agency of Japan.

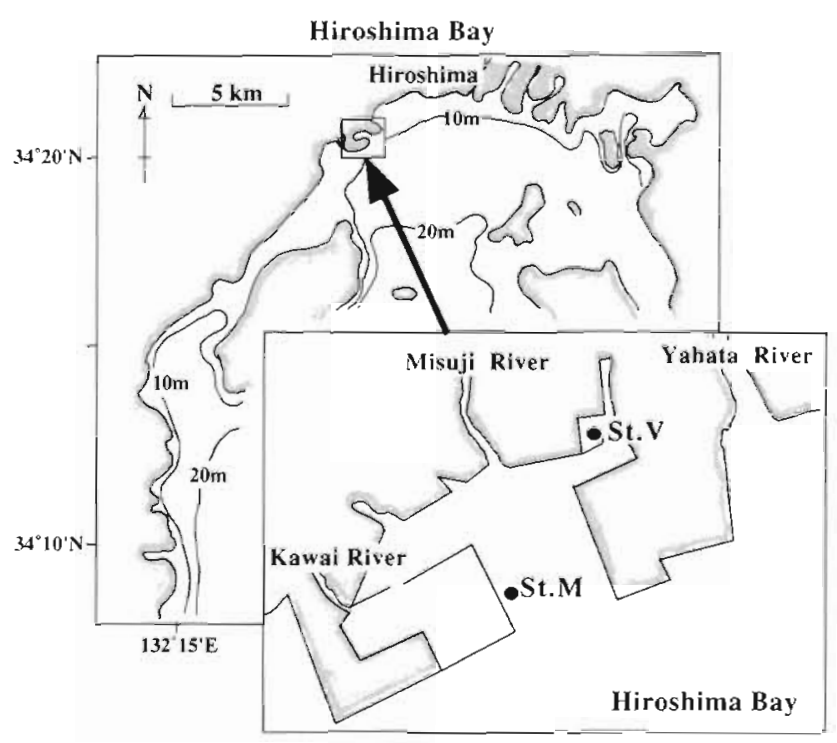

Fig. 1. Sampling sites for investigation of algicidal bacteria targeting Heterosigma akashiwo in Hiroshima Bay, Japan

They were cultivated in a SWM-3 medium (Itoh \& Imai 1987 ) at $20^{\circ} \mathrm{C}$ under an illumination of about $50 \mu \mathrm{mol}$ photons $\mathrm{m}^{-2} \mathrm{~s}^{-1}$ with a $14 \mathrm{~h}$ light: 10 h dark photo-cycle.

Sampling. Seawater samples were collected from the surface and from $1 \mathrm{~m}$ above the bottom at Stn V (ca $5 \mathrm{~m}$ water depth) and Stn M (ca $12 \mathrm{~m}$ water depth) in Hiroshima Bay (Fig 1) (Nagasaki et al. 1994). Sampling was performed between 09:30 and 10:30 h, 1 or 2 times a week from May 24 to July 4 in 1994, and from May 30 to July 7 in 1995. The bottom water was collected using a Van Dorn sampler.

The cell numbers of Heterosigma akashiwo and Chattonella antiqua were counted by optical microscopy.

Counting of cell numbers of Heterosigma akashiwo-killing microorganisms (HAKM) and Chattonella antiqua-killing microorganisms (CAKM). The microorganisms algicidal to $H$. akashiwo and $C$. antiqua were enumerated using the MPN method (Yoshinaga et al. 1995b, Imai et al. 1998) with microalgal cultures as shown in Fig. 2. The log phase cultures of $H$. akashiwo and $C$. antiqua were diluted with SWM-3 to ca $5 \times 10^{4}$ cells $\mathrm{ml}^{-1}$ and ca $10^{3}$ cells $\mathrm{ml}^{-1}$, respectively, and $0.5 \mathrm{ml}$ portions were pipetted aseptically into 48 well microtiter plates (Costar Co.). The seawater samples were filtered through a nuclepore filter $(0.8$ or $0.2 \mu \mathrm{m}$ pore size) and diluted serially with autoclaved seawater. A portion of each diluted sample $(0.5 \mathrm{ml})$ was inoculated into each well of the 48 -well microtiter plates containing the $H$. akashiwo or $C$. antiqua culture. The assay cultures in the microtiter plates were incubated under the same conditions described above for the algal cultures, and the survival of phytoplank- 


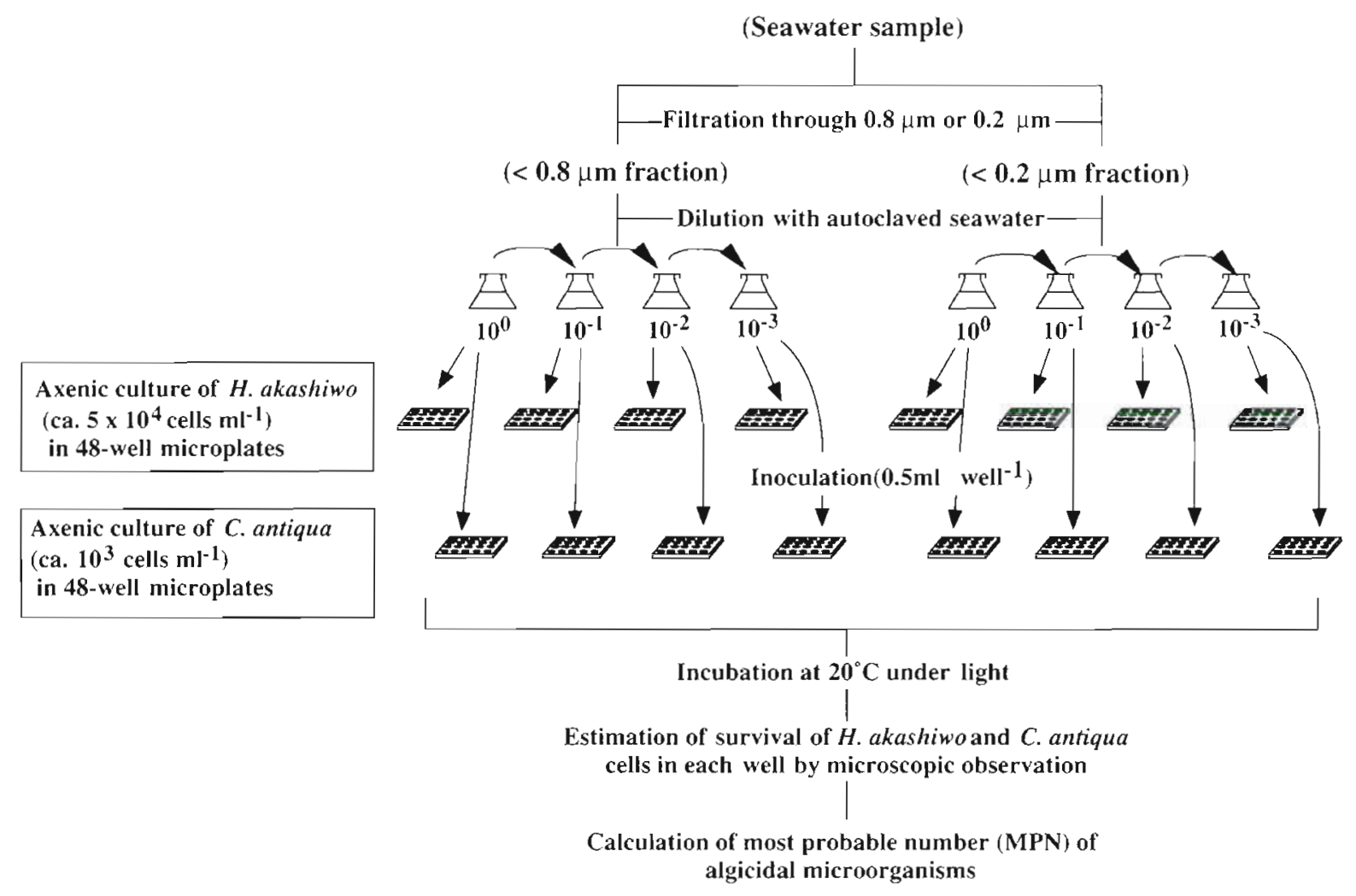

Fig. 2. Experimental procedure of the most probable number (MPN) method for counting Heterosigma akashiwo-killing microorganisms (HAKM) and Chattonella antiqua-killing microorganisms (CAKM) in seawater Seawater samples were collected from the surface and $1 \mathrm{~m}$ above the bottom at Stns $V$ and $M$ (Fig. 1) and filtered through a $0.8 \mu \mathrm{m}$ or a 0.2 m nuclepore filter before inoculation. The seawater sample was serially diluted with autoclave-sterilized seawater, and the portions (0.5 ml) of diluted seawater samples were inoculated to $H$. akashiwo or $C$. antiqua cultures $(0.5 \mathrm{ml})$ in 48 -well microplates. After cultivation under the conditions used for microalgae, the survival of each microalga was detected by microscopy; MPNs of HAKM and CAKM were determined from the series of wells in which microalgae were killed, using a computer program (Nishihara et al. 1986)

ton in each well was assessed daily with an inverted microscope. The wells in which more than $99 \%$ of microalgal cells were destroyed were scored as 'positive', and the MPN of the algicidal microorganisms against $H$. akashiwo and $C$. antiqua was calculated using a microcomputer program (Nishihara et al. 1986, Koch 1994). Autoclaved seawater and seawater filtered through a nuclepore filter $(0.1 \mu \mathrm{m})$ were inoculated into assay cultures for negative controls.

Isolation of Heterosigma akashiwo-killing bacteria (HAKB). Some strains of HAKB were isolated from the wells in which the $H$. akashiwo cells were destroyed. Wells with as high a dilution factor as possible were selected to isolate dominant species among HAKB populations, and subsamples were spread onto a ST10 ${ }^{-1}$ agar plate (Ishida et al. 1986, Yoshinaga et al. $1995 \mathrm{~b}$ ). After $2 \mathrm{wk}$ of growth at $20^{\circ} \mathrm{C}$, bacterial colonies on the agar plates were randomly picked and inoculated again into the $\log$ phase cultures $(3.5 \mathrm{ml})$ of $H$. akashiwo in test tubes $(130 \mathrm{~mm} \times 13 \mathrm{~mm})$ to confirm their killing activities on $H$. akashiwo. Strains desig- nated MC10 and GY14 which had strong killing activity were isolated. The former was from the surface water at Stn $M$ on June 3, 1994, when the $H$. akashiwo bloom was developing, and the latter was from the surface water at Stn $\mathrm{V}$ on June 6, 1994, when the $H$. akashiwo bloom diminished.

Killing activities of $\mathrm{HAKB}$ strains on Heterosigma akashiwo. Two strains (MC10 and GY14) of HAKB, which were previously cultivated in ST10 $10^{-1}$ medium, were inoculated into triplicate log phase cultures ( $3.5 \mathrm{ml}$ ) of $H$. akashiwo (ca $5 \times 10^{4}$ cells $\mathrm{ml}^{-1}$ ) in a test tube at the initial bacterial densities of ca $10^{3}$ or $10^{6}$ cells $\mathrm{ml}^{-1}$. The phytoplankton and bacteria co-cultures were incubated under the conditions used for phytoplankton cultivation. The phytoplankton's growth in each tube was monitored by in vivo autofluorescence derived from chlorophyll excited by blue light, using a Turner fluorometer (Model 102, Turner Co.) (Yoshinaga et al. 1995b). Bacterial cell counts were determined by direct observation using an epifluorescence microscope after DAPI staining (Porter \& Feig 1980). 


\section{RESULTS}

\section{Abundance of Heterosigma akashiwo and HAKM}

The abundances of Heterosigma akashiwo and HAKM in the $<0.8 \mu \mathrm{m}$ and $<0.2 \mu \mathrm{m}$ size fractions were determined in the surface and the bottom seawaters at Stn V in 1994 and 1995 (Fig. 3). In 1994, H. akashiwo bloomed at the surface, attaining a density of more than $10^{4}$ cells $\mathrm{ml}^{-1}$ from June 1 to June 5 and forming a red tide. The bloom decayed suddenly and no $H$. akashiwo cells were detected in the surface seawater on June 6,1994 . In contrast, the number of HAKM in the $<0.8 \mu \mathrm{m}$ fraction increased rapidly from 3 cells $\mathrm{ml}^{-1}$ on June 3,1994 , to $2.6 \times 10^{2}$ cells ml ${ }^{-1}$ on June 6,1994 , when the bloom disintegrated. At that time, however, the number of HAKM in the $<0.2 \mu \mathrm{m}$ fraction did not increase and remained below 1 cell $\mathrm{ml}^{-1}$. A few days after blooming in the surface water, the cell number of $H$. akashiwo in the bottom water also attained more than $10^{4}$ cells $\mathrm{ml}^{-1}$ on June 6,1994 , and then gradually diminished. The HAKM in the $<0.8 \mu \mathrm{m}$ fraction increased to $0.9 \times 10^{2}$ cells ml ${ }^{-1}$ on June 13,1994 , and remained higher than $0.5 \times 10^{2}$ cells $\mathrm{ml}^{-1}$ cell density until July 1, 1994. In 1995, the number of $H$. akashiwo started to increase on June 20 and formed a red tide at a cell density of more than $2 \times 10^{4}$ cells ml $^{-1}$ at the sur- face from June 23 to June 30,1995 , and thereafter declined rapidly. Similar to the occurrence in 1994, HAKM in the $<0.8 \mu \mathrm{m}$ fraction increased just before the decline of the $H$. akashiwo bloom and attained a value of $1.5 \times 10^{2}$ cells $\mathrm{ml}^{-1}$ on June 30,1995 , which is an abundance about 100 times greater than before the bloom. Throughout the experimental period, the HAKM in the $<0.2 \mu \mathrm{m}$ fraction was hardly detectable in either the surface or the bottom waters.

The fluctuations of Heterosigma akashiwo and HAKM abundance in the surface and the bottom waters at Stn M in 1994 and 1995 are shown in Fig. 4. Though the cell density of $H$. akashiwo did not exceed $10^{4}$ cells $\mathrm{ml}^{-1}$ and did not form a visible red tide during the experimental period at Stn M, the HAKM in the $<0.8 \mu \mathrm{m}$ size fraction increased when $H$. akashiwo decreased. The number of HAKM in the $<0.2 \mu \mathrm{m}$ fraction was generally less than that in the $<0.8 \mu \mathrm{m}$ fraclion, as was the case at $\operatorname{Stn} V$.

\section{Comparison of HAKM and CAKM}

The fluctuations of CA.KM abundance in the $<0.8 \mu \mathrm{m}$ size fraction in the surface and the bottom seawaters at both Stns V and M were also investigated in 1994 and 1995, and determined in the same manner as HAKM

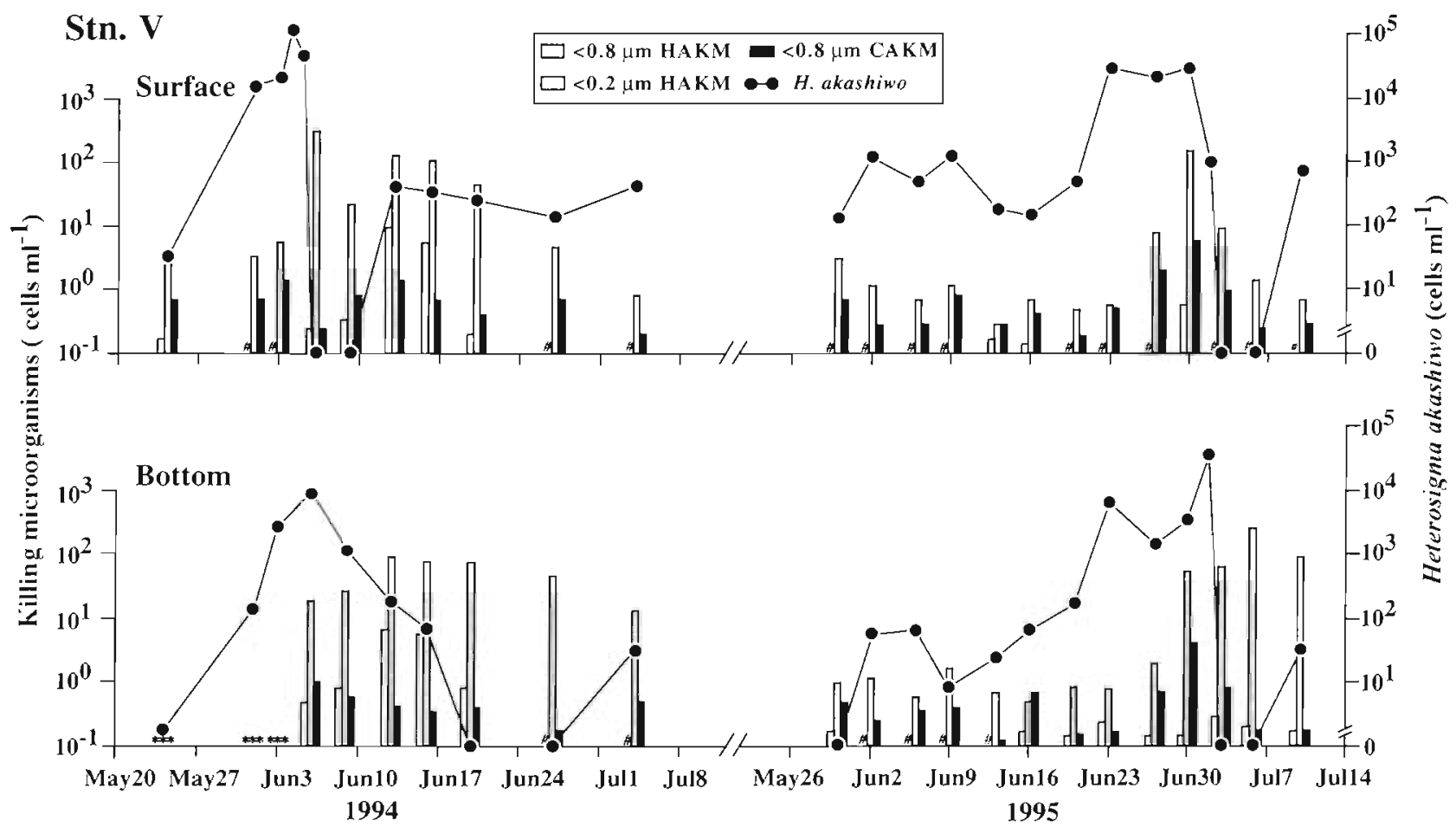

Fig. 3. Abundance of Heterosigma akashiwo. HAKM in the $<0.8 \mu \mathrm{m}$ and $<0.2 \mu \mathrm{m}$ seawater fractions, and Chattonella antiquakilling microorganusms (CAKM) in the $<0.8 \mu \mathrm{m}$ seawater fraction at $\mathrm{Stn} V$ in 1994 and 1995 . Seawater samples were collected from the surface and from $1 \mathrm{~m}$ above the bottom. \#: not detected; * not examined 


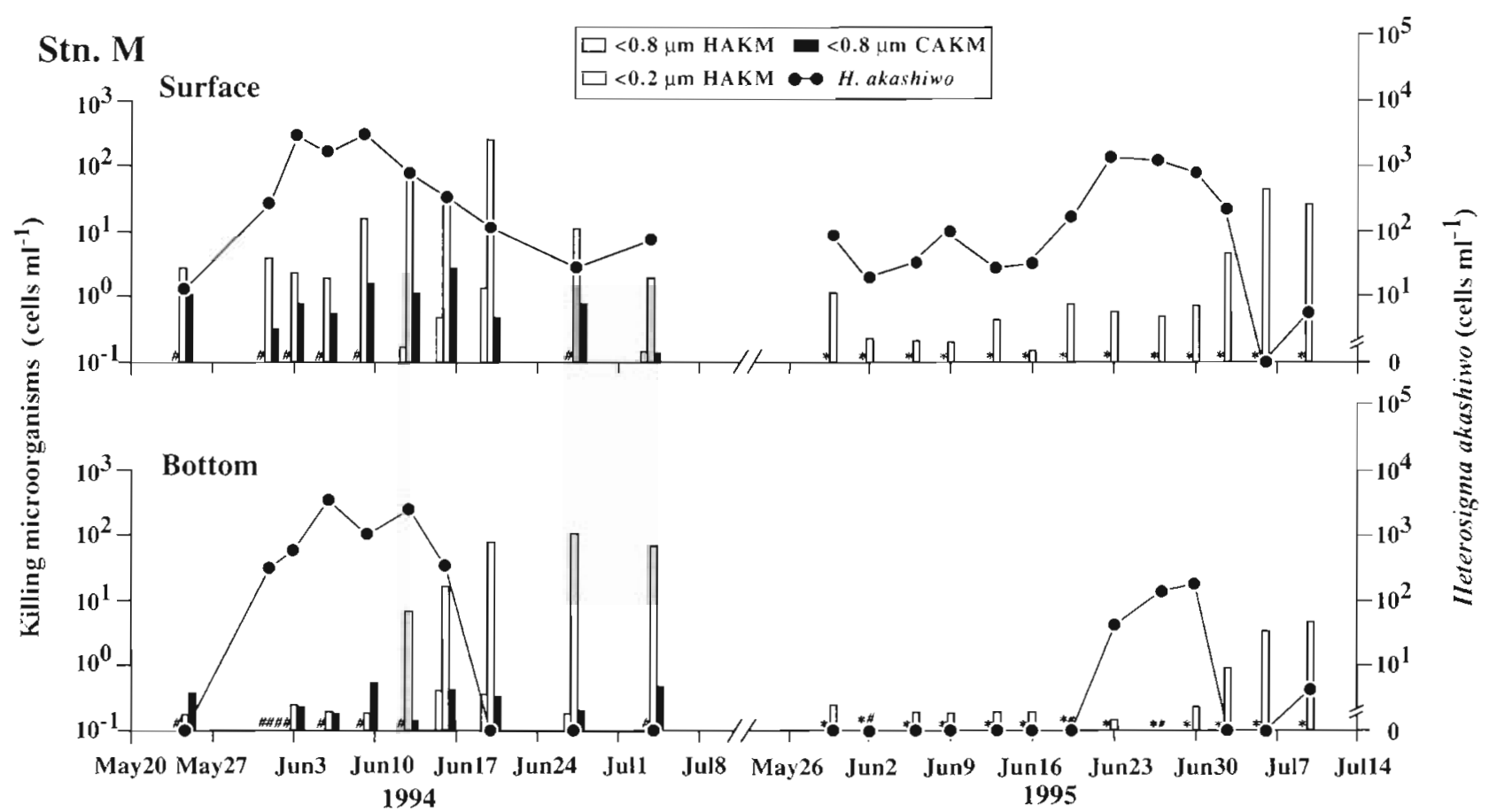

Fig. 4. Abundance of Heterosigma akashiwo, HAKM in the $<0.8 \mu \mathrm{m}$ and $<0.2 \mu \mathrm{m}$ seawater fractions, and Chattonella antiquakilling microorganisms (CAKM) in the $<0.8 \mu \mathrm{m}$ seawater fraction at Stn $\mathrm{M}$ in 1994 and 1995. Seawater samples were collected from the surface and from $1 \mathrm{~m}$ above the bottom. \#: not detected; *: not examined

(Figs. 3 \& 4). Chattonella antiqua cells were not detected at either sampling site in Hiroshima Bay during the experimental period in either 1994 or 1995.

In 1994, the abundance of CAKM at Stn $V$ ranged from 0.2 to 1.3 cells $\mathrm{ml}^{-1}$ in both the surface and bottom waters, even when the abundance of HAKM were more than $10^{2}$ cells $\mathrm{ml}^{-1}$ (Fig. 3). The CAKM abundance in both the surface and bottom waters at Stn $V$ increased up to 5.6 and 3.8 cells $\mathrm{ml}^{-1}$, respectively, on June 30, 1995, but corresponded to only about 4 and $6 \%$ of the HAKM abundance at that time (Fig. 3). Also, in the surface and bottom water samples at Stn M, the fluctuation of CAKM abundance did not correlate with the fluctuation of Heterosigma akashiwo and HAKM abundances, and ranged at a low level between 0.1 and 2.6 cells ml-1 $^{-1}$ (Fig. 4).

\section{Isolation of $\mathrm{HAKB}$}

Several hundred bacterial strains which have killing activities on Heterosigma akashiwo were isolated from the cultures in microtiter plate wells used for the MPN counting of HAKM, and were designated $H$, akashiwokilling bacteria. From the wells inoculated with the $<0.2 \mu \mathrm{m}$ fraction of seawater samples, no HAKB strains could be isolated.

Fig. 5 shows the typical killing effects of 2 HAKB isolates (MC10 and GY14) against the log phase culture of Heterosigma akashiwo. When the bacterial isolates were added at the initial cell density of $10^{6}$ cells $\mathrm{ml}^{-1}$, the autofluorescence derived from chlorophyll of $H$.

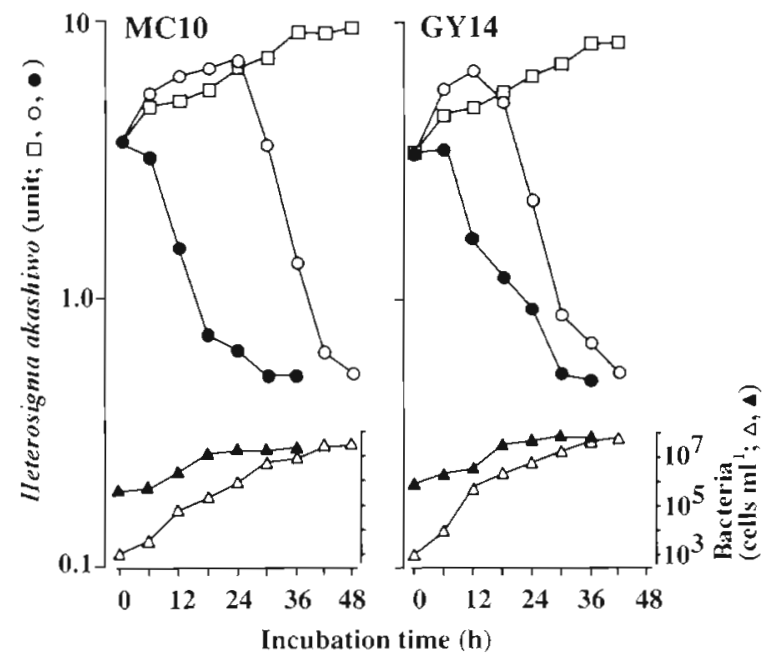

Fig. 5. Inhibitory effect of HAKB strains (MC10 and GY14) on the growth of Heterosigma akashiwo. Bacterial cells were inoculated at the initial cell densities of $10^{3}$ cells $\mathrm{ml}^{-1}$ ( $\triangle$ : bac-

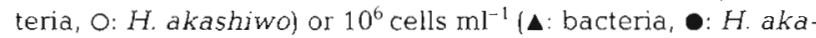
shiwo). The growth and survival of $H$. akashiwo with bacteria $(0, \bullet)$ and without bacteria ( $\square$ ) were monitored by the autofluorescence emitted from chlorophyll of phytoplankton cells using a Turner Fluorometer The numbers of bacteria $(\Delta, \mathbf{\Delta})$ were determined using the direct counting method with DAPI staining 
akashiwo cells decreased immediately and was less than $10 \%$ of the initial fluorescence after $30 \mathrm{~h}$. At that time, the destruction of most algal cells in the culture was verified by microscopic observation. As the abundance of $H$. akashiwo cells decreased, the bacterial cell number increased to more than $5 \times 10^{7}$ cells $\mathrm{ml}^{-1}$ during the co-cultivation. When the initial cell densities of strains MC10 and GY14 were $10^{3}$ cells $\mathrm{ml}^{-1}$, the bacterial cell densities reached more than $10^{6}$ cells $\mathrm{ml}^{-1}$ after $24 \mathrm{~h}$ and $12 \mathrm{~h}$ incubation, respectively, and the autofluorescence of the phytoplanktonic cells diminished.

\section{DISCUSSION}

It has been frequently observed that the termination of phytoplankton blooms in seawater and freshwater environments occurs abruptly. In this study, the blooms of Heterosigma akashiwo in 1994 and 1995 also disintegrated within a few days in the surface water at Stn V in Hiroshima Bay (Fig. 3). The number of HAKM in the $<0.8 \mu \mathrm{m}$ size fraction, however, increased dramatically at the end of the blooms or during the decay of the blooms at both sampling sites in 1994 and 1995 (Figs. 3 \& 4). Because bacterial grazers, such as heterotrophic nanoflagellates, and other phytoplankton species were likely removed for the most part by the filtration through the $0.8 \mu \mathrm{m}$ membrane, the microorganisms in the $<0.8 \mu \mathrm{m}$ size fraction were bacteria and viruses. These results suggest that the bacteria and/or viruses in seawater might influence the dramatic disintegration of $H$. akashiwo blooms.

Generally, the MPN counts of HAKM in the $<0.2 \mu \mathrm{m}$ size fraction were 1 or 2 orders of magnitude less than those in the $<0.8 \mu \mathrm{m}$ size fraction, although in several cases the former increased during the disintegration periods of the blooms. This result suggests that the HAKM in the $<0.8 \mu \mathrm{m}$ fraction seems mainly to consist of bacteria. Several researchers have pointed out the importance of viral activity with respect to bloom dynamics of phytoplankton in the ocean (Suttle 1994, Bratbak et al. 1995). Nagasaki et al. (1994) showed by electron microscopic observation that the amount of VLPs increased in Heterosigma akashiwo cells at the termination period of the bloom by $H$. akashiwo in 1993 in Hiroshima Bay. Though the results in this study show that the bacterial impact was more significant on the decrease of $H$. akashiwo cells than the viral impact in 1994 and 1995, the viral infection to H. akashiwo is not negligible and it may be a potential agent regulating the bloom of $H$. akashiwo, because no algicidal bacteria were isolated from any wells in which the destruction of the algal cells occurred after inoculation with the $<0.2 \mu \mathrm{m}$ size fraction of seawater samples. In those wells algal lytic pathogens other than bacteria, presumably viruses, or some chemical substances which kill the phytoplankton might exist. But we could not obtain more information about this phenomenon.

We isolated many strains of HAKB during the experimental period in both 1994 and 1995. All of them, including strains MC10 and GY14, had strong algicidal activities, destroying Heterosigma akashiwo within a few days of co-cultivation (Fig. 5). Restriction fragment length polymorphism (RFLP) analysis of $16 \mathrm{~S}$ rRNA genes of those isolates showed that the HAKB populations consist of at least 17 different groups of bacteria (Yoshinaga et al. 1998, in this issue). There are tens of strains of bacteria algicidal to marine phytoplankton which have been isolated from seawater so far, and most of them grow in sterilized seawater without the addition of organic nutrients (Imai et al. 1993a, 1995. Yoshinaga et al. 1995a, 1997). These authors speculated that those algicidal bacteria were ubiquitous in seawater and influenced the phytoplankton bloom opportunistically. The number of HAKB generally persisted for a long period after disappearance of the $H$. akashiwo bloom, so it is possible to say that the HAKB are present irrespective of phytoplankton blooms in marine environments. Three groups of HAKB classified by the RFLP were generally predominant at the termination period of the blooms at all sampling sites, and hence they seem to have a close relationship to the decay process of the bloom (Yoshinaga et al. 1998).

The abundance of microorganisms which kill another noxious marine raphidophycean flagellate, Chattonella antiqua, did not increase during the collapse of the $H$. akashiwo blooms (Figs. 3 \& 4). This result implied that most of the HAKB which increased. at the termination periods of $H$. akashiwo blooms in 1994 and 1995 did not affect the growth of C. antiqua. Fukami et al. (1992) isolated a bacterium which killed the dinoflagellate Gymnodinium mikimotoi but did not kill the diatom Skeletonema costatum. Yoshinaga et al. (1997) also isolated some Gm-GIB strains which had an inhibitory effect on the growth of $G$. mikimotoi but did not effect on the growth of 3 species of marine diatoms. These results show the possibility that these bacteria regulate the structure of phytoplankton communities in marine environments.

In a previous paper, we pointed out a methodological problem in the MPN counting procedure which uses phytoplankton cultures as assay media and suggested that the MPN values of bacteria effecting the phytoplankton growth may be underestimated (Yoshinaga et al. 1995b). We have already observed the existence of bacteria which promote the growth of some marine phytoplankton and bacteria which inhibit the ability of some algicidal bacteria to kill in seawater. Therefore, when a seawater sample was diluted and inoculated in the assay medium for MPN counting, 
heterogeneous and many other different kinds of bacteria which may possess inhibitory or stimulatory effects to phytoplankton growth were inoculated before cultivation. Furthermore, the algicidal activities in each assay culture may be determined finally by the sum of activities of co-existing bacteria. In this study, the numbers of $\mathrm{HAKB}$ even at their peaks were relatively low, $10^{2} \mathrm{ml}^{-1}$ at most; this was because, as a result of using the MPN method, the abundance of HAKB was underestimated. Moreover, in the laboratory conditions, some HAKB isolates needed cell densities of more than $10^{6}$ cells $\mathrm{ml}^{-1}$ to cause total mortality of phytoplankton (Fig. 5). Probably, more accurate information about $\mathrm{HAKB}$ distribution and dynamics in natural environments will make clear how important the HAKB population impact on algal blooms is. Some in situ detection techniques with DNA probes or antibodies that can specifically recognize HAKB must be developed to elucidate the real dynamics of those bacteria in coastal water.

Application of HAKB may be useful to prevent the harmful red tide of Heterosigma akashiwo, with less of a harmful influence on a marine environment than chemical methods. Further studies on the characteristics and killing mechanisms of HAKB are essential for application of the bacteria as regulatory agents of harmful red tides.

Acknowledgements. We are grateful to Professors T. Ikeda of Hokkaido University and T. Honjo of Kyushu University, both former directors of Red Tide Research Division of Nansei National Fisheries Research Institute, Fisheries Agency of Japan, for their support and encouragement, and Dr M. Yamaguchi and colleagues of Nansei National Fisheries Research Institute, for collection of seawater samples in this study. We thank Dr I. Dundas, University of Bergen, Norway, and Dr R. Y. Morita, Oregon State University, USA, for their helpful advice. This study was supported by a grant from the Fisheries Ground Preservation Division, Fisheries Agency of the Japanese Government, and by the grants in aid for Scientific Research (No. 07406010 and No. 06304019) from the Ministry of Education. Science, and Culture, Japan.

\section{LITERATURE CITED}

Anderson DM, Chisholm SW, Watras CJ (1983) Importance of life cycle events in the population dynamics of Gonyaulax tamarensis. Mar Biol 76:179-189

Baker KH, Herson DS (1978) Interactions between the diatom Thallasiosira pseudonanna and an associated pseudomonad in a mariculture system. Appl Environ Microbiol 35:791-796

Bratbak G, Egge JK, Heldal M (1993) Viral mortality of the marine alga Emiliania huxleyi (Haptophyceae) and termination of algal blooms. Mar Ecol Prog Ser 93:39-48

Bratbak G, Levasseur M, Michaud S, Cantin G, Fernandez E, Heimdal BR, Heldal M (1995) Viral activity in relation to Emiliania huxleyi blooms: a mechanism of DMSP release? Mar Ecol Prog Ser 128:133-142
Cole JJ (1982) Interaction between bacteria and algae in aquatic ecosystems. Annu Rev Ecol Syst 13:291-314

Fukami K, Nishijima T, Murata H, Hata Y (1991) Distribution of bacteria influential on the development and the decay of Gymnodinium nagasakiense red tide and their effects on algal growth. Nippon Suisan Gakkaishi 57:2321-2326

Fukami K, Yuzawa A, Nishijima T, Hata Y (1992) Isolation and properties of a bacterium inhibiting the growth of Gymnodinium nagasakiense. Nippon Suisan Gakkaishi 58: 1073-1077

Honjo T (1992) Harmful red tides of Heterosigma akashiwo. NOAA Tech Rep NMFS 111:27-32

Imai I, Ishida Y, Hata Y (1993a) Killing of marine phytoplankton by a gliding bacterium Cytophaga sp., isolated from the coastal sea of Japan. Mar Biol 116:527-532

Imai I, Ishida Y, Sakaguchi K, Hata Y (1995) Algicidal marine bacteria isolated from northern Hiroshima Bay, Japan. Fish Sci 61:624-632

Imai 1, Ishida Y, Sawayama S, Hata Y (1991) Isolation of a marine gliding bacterium that kills Chattonella antiqua (Raphidophyceae). Nippon Suisan Gakkaishi 57:1409

Imai I, Itakura S, Itoh K (1993b) Cyst of the red tide flagellate Heterosigma akashiwo, Raphidophyceae, found in bottom sediments of northern Hiroshima Bay, Japan. Nippon Suisan Gakkaishi 59:1669-1673

Imai I, Kim MC, Nagasaki K, Itakura S, Ishida Y (1998) Detection and enumeration of killer microorganisms against harmful phytoplankton in the coastal sea. Plankton Biol Ecol 45:15-25

Ishida Y, Eguchi M, Kadota H (1986) Existence of obligately oligotrophic bacteria as a dominant population in the South China Sea and the West Pacific Ocean. Mar Ecol Prog Ser 30:197-203

Ishio O, Mangindaan RE, Kuwahara M, Nakagawa H (1989) A bacterium hostile to flagellates: identification of species and characters. In: Okaichi T, Anderson DM, Nemoto T (eds) Red tides: biology, environmental science, and toxicology. Elsevier, New York, p 205-208

Itoh K, Imai I (1987) Raphido so (Raphidophyceae). In: Japan Fisheries Resource Conservation Association (ed) A guide for studies of red tide organisms. Shuwa, Tokyo, p 122-130 (in Japanese)

Jeong HJ, Latz MI (1994) Growth and grazing rates of the heterotrophic dinoflagellate Protoperidium spp. on red tide dinoflagellates. Mar Ecol Prog Ser 106:173-185

Jones AK (1982) The interaction of algae and bacteria. In: Bull AT, Slater JK (eds) Microbial interaction and communities. Academic Press, New York, p 189-247

Kamiyama T (1994) The impact of grazing by microzooplankton in northern Hiroshima Bay, the Seto Inland Sea, Japan Mar Biol 119:77-88

Kamiyama T (1995) Change in the microzooplankton community during decay of a Heterosigma akashiwo bloom J Oceanogr 51:279-287

Koch AL (1994) Growth measurement. In: Gerhardt P, Murray RGE, Wood WS, Krieg NR (eds) Methods for general molecular bacteriology. Am Soc Microbiol, Washington, DC, p 248-277

Mitsutani A, Takesue K, Kirita M, Ishida Y (1992) Lysis of Skeletonema costatum by Cytophaga sp. isolated from the coastal water of the Ariake Sea. Nippon Suisan Gakkaishi 58:2158-2167

Nagasaki K, Ando M, Imai I, Itakura S, Ishida Y (1993) Viruslike particles in an apochlorotic flagellate in Hiroshima Bay, Japan. Mar Ecol Prog Ser 96:307-310

Nagasaki K, Ando M, Itakura S, Imai I, Ishida Y (1994) Viral mortality in the final stage of Heterosigma aka- 
shiwo (Raphidophyceae) red tide. J Plankton Res 16: 1595-1599

Nakamura Y, Suzuki SY, Hiromi J (1995) Population dynamics of heterotrophic dinoflagellates during a Gymnodinium mikimotoi red tide in the Seto Inland Sea. Mar Ecol Prog Ser 125:269-277

Nakamura Y, Yamazaki Y, Hiromi J (1992) Growth and grazing of a heterotrophic dinoflagellate, Gyrodinium dominans, feeding on a red tide flagellate, Chattonella antiqua. Mar Ecol Prog Ser 82:275-279

Nishihara T, Kurano N, Shinoda S (1986) Calculation of Most Probable Number for enumeration of bacteria on a microcomputer. Eisei Kagaku 32:226-228 (in Japanese)

Porter KG, Feig YS (1980) The use of DAPI for identifying and counting aquatic microflora. Limnol Oceanogr 25:943-948

Riquelme CE, Ishida Y (1989) Interaction between microalgae and bacteria in coastal seawater Mem Coll Agric Kyoto Univ 134:1-60

Sakata I (1990) Occurrence of marine Saprospira sp. possessing algicidal activity for diatoms. Nippon Suisan Gakkaishi 56:1165

Suttle CA (1994) The significance of viruses to mortality in aquatic microbial communities. Microb Ecol 28:237-243

Editorial responsibility: Jed Fuhrman (Contributing Editor), Los Angeles, California, USA
Suttle CA. Chan AM (1995) Viruses infecting the marine prymnesiophyte Chrysochromulina spp.: isolation, preliminary characterization and natural abundance. Mar Ecol Prog Ser 118:275-282

Yoshinaga I. Kawai T, Ishida Y (1995a) Lysis of Gymnodinium nagasakiense by marine bacteria. In: Lassus P, Arzul $G$, Erard E, Gentien P, Marcallou C (eds) Harmful marine algal blooms. Lavoisier Publishing. Paris, p 687-692

Yoshinaga I, Kawai T, Ishida Y (1997) Analysis of algicidal ranges of the bacteria killing the marine dinoflagellate, Gymnodinium mikimotoi, isolated from Tanabe Bay. Wakayama Pref Japan. Fish Sci 63:94-98

Yoshinaga I, Kawai T, Takeuchi T, Ishida Y (1995b) Distribution and fluctuation of bacteria inhibiting the growth of a marine red tide phytoplankton Gymnodinium mikimotoi in Tanabe Bay (Wakayama Pref Japan). Fish Sci 61: $780-786$

Yoshinaga I, Kim MC, Katanozaka N, Imai I, Uchida A, Ishida Y (1998) Population structure of algicidal marine bacteria targeting the red tide forming alga Heterosigma akashiwo (Raphidophyceae), determined by restriction fragment length polymorphism analysis of the bacterial $16 \mathrm{~S}$ ribosomal RNA genes. Mar Ecol Prog Ser 170:33-44

Submitted: June 11, 1997; Accepted: April 28, 1998 Proofs received from author(s): August 11, 1998 